\title{
ASSESSMENT OF JOURNALISM STUDENTS' WRITING PROJECTS COMPLETED INDIVIDUALLY AND IN COLLABORATION
}

\author{
Svitlana Fiialka ${ }^{1}$, Olga Trishchuk ${ }^{2}$, Nadija Figol $^{3}$, Tetiana Faichuk ${ }^{4}$ \\ ${ }^{1,2,3}$ National Technical University of Ukraine "Igor Sikorsky Kyiv Polytechnic Institute" \\ ${ }^{4}$ O. O. Potebnia Institute of Linguistics of the National Academy of Sciences of Ukraine
}

fiyalka@i.ua

\begin{abstract}
The authors discuss the issues and benefits of collaborative writing in journalistic education, comparing the texts written by students in different conditions: in group collaboration, individually after prewriting group discussion, and individually without any collaboration. We used a survey for collecting both quantitative and qualitative data. The participants were 21 second year and 15 third-year students, who wrote 18 fiction stories for preschool children ( 3 were written in the collaborative writing groups of 4 , where the students were allowed to choose partners for small groups; 3 in the collaborative writing groups of 4 , where the students were not allowed to choose partners; 6 after prewriting group discussion, and 6 without any collaboration). 12 six-year students evaluated delivered texts. We also interviewed 12 teachers of the Department of Publishing and Editing about the collaborative writing tasks at the meeting of the Department. Teachers' interviews were recorded, transcribed and analysed. The students and teachers expressed positive attitudes towards collaborative writing, that contributes to students' learning outcomes and prepare them for teamwork. The highest score got the texts written individually after the prewriting discussion. The stories written by the students who were allowed to choose partners in a group work gained higher scores than texts prepared in randomly created groups. The participants in the selfselected conditions reported that they enjoyed a high level of participation, sharing the workload and supportive behaviour. We also observed the evidences of unequal participation of students in collaboration in small groups where the partners were not familiar. The lowest average score got the texts written with no collaboration. So, we proved that there is a need for implementing prewriting group discussions in the learning process. It is necessary to differentiate the role of each student in collaborative writing to evaluate individual results correctly.
\end{abstract}

Keywords: journalistic education; collaboration; collaborative writing; individual writing; group work; prewriting group discussion; writing task.

\section{Introduction.}

Collaborative writing is typically defined as the joint production of a text or the coauthoring of a text by two or more writers (Storch, 2011). It is especially relevant in journalistic education. Journalists, public relations agents and copywriters often collaborate, working on their social or advertising projects and writing texts for print newspapers, journals or internet media. So, it is extremely important to give students collaborative writing tasks to prepare them to write in teams after they graduate.

Collaborative writing is an effective strategy in both traditional face-to-face and online environments (Zheng et al., 2018). Through this form of learning, students interact with each other and with a teacher to ask questions, discuss ideas, find solutions, complete tasks and reflect on their experiences (Kozlov and Große, 2016). Collaborative writing teaches students how to be "tactful, constructive, sympathetic, and firm all at once" (Bruffee, 2007).

An essential activity in collaborative writing is a prewriting discussion, when writers generate ideas, explore directions, and search their way for writing. When students attempt to write texts without developing ideas, designing the structure of their texts, and focusing on the precision with words and phrases, they can end up with a "premature draft", "one that is more writer-based than reader-based and, thus, might not be received by readers in the way the writer intended" (Inoshita, Garland and Sims, 2019). When writing individually without any prewriting group discussion, students work in isolation, and their performance is determined by purposeful, internal motivation and abilities for learning. Collaborative writing does not isolate students from each other, but allows them to improve communicative skills, develops the skills of planning, self-control and peer control. It becomes particularly relevant in the situation when teamwork has moved from a desirable skill to an essential requirement from employers (Riebe, Girardi and Whitsed, 2016).

Collaborative writing includes the interdependent effort of multiple people to achieve a common goal (Wilson, Ho and Brookes, 2017). There are clear benefits, but unless students acquire the skills to interact effectively in groups, the outcome may lead to resentment and frustration (Baker and Clark, 2010). In other

(C) Svitlana Fiialka, Olga Trishchuk, Nadija Figol, Tetiana Faichuk. 2021. Published by Igor Sikorsky Kyiv Polytechnic Institute. This is an Open Access article distributed under the terms of the licence CC BY 4.0 
words, the lack of interpersonal and teamwork skills may stifle collaborative writing (Le, Janssen and Wubbels, 2017).

Unfortunately, traditional journalistic education considers writing as predominantly an individual activity. Both students and employers perceive that the graduates experience a lack of interpersonal communicative and collaborative skills (Prinsley and Baranyai, 2015). Students extremely rarely engage in extensive dialogue with their peers when writing. Meanwhile, much writing in the workplace takes place in collaboration with colleagues on all stages of writing from decision-making to text construction and editing.

Collaborative writing is the topic of numerous academic papers. It is an activity in which students interact and negotiate with each other, and make joint decisions throughout the writing process and produce a single text with shared responsibility and co-ownership (Storch, 2013, Diezmann, 2005). Collaborative writing may help students generate ideas, organise them, and set goals (Kellogg, 1990). Teamwork writing assessments create a more comprehensive educational experience by broadening the diversity of skills that students develop (Wilson, Ho and Brookes, 2017) within the context of a group (Baker, Day and Salas, 2006).

We define collaborative writing (based on the definitions of Ayodele et al., 2017; Hei et al., 2014) as a method when students are encouraged or required to work together on writing tasks. This method offers students the opportunity to develop both cognitive skills, like analysing and problem-solving, and social behaviour, like empathy and help. Even if only one person literally writes the text, another person contributing ideas has an effect on the final text.

By working in a group, the developed idea is likely to be more creative. Writing involves complicated and "multifaceted activities such as generating ideas, drafting, revising, editing texts, and correcting errors. It can be seen that writing is a long and continuous process" (Wahyudi, Hilaluddin and Ader, 2018). Collaborative pattern refers to the type of interaction in which students exhibit a high degree of close collaboration. But they may behave differently during a collaborative writing process due to their contrasting attitudes towards the activity (Chen and $\mathrm{Yu}, 2019$ ).

Participants' life trajectories, communicative strategies, personal circumstances, and the affordances of the technology mediate students' participation in collaborative writing ( $\mathrm{Li}$ and $\mathrm{Kim}, 2016)$. Students' roles in collaboration have different patterns of behavioural engagement (active or passive, leading or following), contribution characteristics (providing new information or echoing given material), and social position (individual or group) (Dowell, Nixon, and Graesser, 2018).

The linguistic features and overall quality of students' texts written collaboratively are higher, so the process of co-construction is advantageous (McDonough and García Fuentes, 2015, Wigglesworth and Storch, 2009). Collaboratively written texts are more accurate than individual texts, with accuracy benefits attributed to students' discussions (Fernandez Dobao, 2012, McDonough and García Fuentes, 2015, Storch, 2005). Meanwhile, collaborative writing tasks generally take longer to complete than individual writing as students require more time to interact (Diezmann, 2005).

Gardner (2017) offered a narrative of a youth-adult team's experience of writing together for publication; a process that moved them from initial "distance and distaste" to an experience of transformative team engagement. It illustrates potential ways that teams can draw from the partnership and academic writing cultures to create a team co-writing process. In an international study involving over 17,000 students, Roseth et al. (2008) showed that students involved in a collaborative writing experience achieved higher academic results than those in an individualistic learning environment. Hashem (2018) investigated the effectiveness of online blogging for students' individual and group writing skills. Blogging-based writing practice is more participatory and interactive, and learners can dramatically improve their writing skills in terms of content, word choice, style, language mechanics and the like.

Reviews of 21 representative articles on collaborative writing published from 2008 to 2017 in top-tier peer-refereed journals revealed that with the development of Web 2.0 tools (e.g. Wikis, Google docs) that afford participation and collaboration at an unprecedented level, computer-mediated collaborative writing has gained increasing attention (Li, 2018). Lamminpää and Vesterinen (2018) proved that humour had an integral role in collaborative decision-making, for example in proposing and evaluating new ideas. Humour is used to create a group identity and to regulate negative emotions such as anxiety, frustration, uncertainty, boredom and disappointment.

The considered articles about collaborative writing at universities are found predominantly in academic journals on business communication. More research is needed about the perceptions of students' and teachers' attitudes towards collaborative writing in order to gain a better understanding of learners' behaviour and learning outcomes of collaborative writing tasks. So, we try to fill the gap in academic literature, gathering background for collaborative writing education, based on the opinions of students and teachers and the results of experimental research. 
Research aims are to highlight issues and benefits of collaborative writing in journalistic education, compare the texts written by students under different conditions, including prewriting discussions, and identify different writing behaviour in groups.

Research questions are following:

1. Is there a difference in the quality of texts written by students in collaboration, collaboration before writing followed by individual writing, and individually?

2. What students' and university teachers' attitudes towards collaborative writing tasks are?

\section{Method.}

In order to verify the hypothesis of our research, we chose a mixed research methodology framework (Creswell, 2014) for the research performance. The experimental study was conducted at National Technical University of Ukraine "Igor Sikorsky Kyiv Polytechnic Institute" (Kyiv, Ukraine).

\section{Participants}

The participants of the study, who wrote the texts, were second $(n=21)$ and third-year students $(n=15)$. 12 six-year students and 12 teachers at the Department of Publishing and Editing participated as experts. Before conducting the research we informed students that their participation was voluntary, anonymous and would not affect their grades.

\section{Materials}

We used a survey to collect quantitative and qualitative data on the advantages and disadvantages of collaborative writing. 2 survey questionnaires revealed the perceptions and attitudes of university teachers and students about collaborative writing. Teachers' interviewing helped us to gather data on collaborative writing tasks that they use in teaching and analyse their attitudes.

\section{Procedure and data analysis}

On the first stage each of 36 second and third-year students were assigned to carry out a writing task (a fiction story for pre-school children up to 1000 words for preschool children) under different writing conditions: in the collaborative writing groups (24 students in 6 groups of 4 people), after prewriting group discussion (6 students had an opportunity to discuss their ideas related to writing task with each other before writing individually), and with no collaboration (6 students did their writing tasks individually without any prewriting discussion).

Initially, the students in the collaborative writing conditions were divided into two large groups. In the first group (12 students) participants were allowed to choose partners for small groups of 4 people. The partners for another 3 small groups of 4 were selected by the teacher. So, there were small groups where the students had an opportunity to work with friends as well as with the students with whom they were not familiar. 24 students collaborated throughout all phases of the writing process. They worked in groups to plan and write their texts. 6 students in the collaborative prewriting group shared ideas and took written notes on the task but wrote individually. Meanwhile, 6 students planned and wrote their texts on their own. The writing task was administered by three university teachers. Students in all 3 types of writing conditions wrote their texts by hand, and were not allowed to use any electronic devices. The students carried out the writing task simultaneously in different learning classrooms. The students performed tasks within 90 minutes. They were explained that there were high expectations of the quality of their work and emphasised that it was their responsibility to proofread work carefully before submission.

The texts were collected in the following order: 1) 6 texts from the collaborative writing groups ( 3 written in the collaborative writing groups of 4 , where the students were allowed to choose partners for small groups; 3 written in the collaborative writing groups of 4 , where the students were not allowed to choose partners), 2) 6 texts written after prewriting group discussion, 3) 6 texts created without any collaboration.

On the second stage, 18 delivered texts written on the first stage were independently and anonymously scored on a 100-point scale by 12 sixth year students immediately after the tasks were completed. The texts were evaluated according to the following criteria: originality of the plot (30), language and style (30), text admissibility for the relevant age category (10), didactic function (10), characters (20).

On the third stage, 24 students who had performed the tasks in collaboration throughout all phases of the writing process completed the questionnaire about the advantages and disadvantages of collaborative text writing. On the fourth stage, 12 teachers of the Department of Publishing and Editing completed the questionnaire and were interviewed about the collaborative writing tasks they use in teaching at the meeting of the Department for 2 hours. Teachers' interviews were recorded on 12 pages, transcribed and analysed. 


\section{Results}

After assigning the writing task, we received 18 texts (3 texts composed in the collaborative writing groups, where the students were allowed to choose partners for small groups; 3 texts written in the collaborative writing groups, where the students were not allowed to choose partners for small groups; 6 texts written individually after prewriting discussion, and 6 texts written individually with no prewriting collaboration). The texts were evaluated by 12 sixth year students. The results that illustrate the differences in the quality of the texts written under different writing conditions are presented in the table 1.

Table 1. Evaluation of the texts written under different conditions

\begin{tabular}{|c|c|c|c|c|c|}
\hline \multirow[t]{2}{*}{ Text number } & \multicolumn{5}{|c|}{ Average score } \\
\hline & $\begin{array}{l}\text { Originality of } \\
\text { the plot }(30)\end{array}$ & $\begin{array}{l}\text { Language and style } \\
\text { (30) }\end{array}$ & $\begin{array}{c}\text { Text } \\
\text { admissibility } \\
(10)\end{array}$ & $\begin{array}{c}\text { Didactic } \\
\text { function } \\
(10)\end{array}$ & Characters (20) \\
\hline \multicolumn{6}{|c|}{$\begin{array}{l}\text { Texts written in the collaborative writing groups, where the students were allowed to choose partners for small } \\
\text { groups }\end{array}$} \\
\hline 1 & 27 & 24 & 9 & 8 & 19 \\
\hline 2 & 26 & 27 & 8 & 9 & 16 \\
\hline 3 & 24 & 25 & 8 & 9 & 16 \\
\hline Average score & 25.7 & 25.3 & 8.3 & 8.0 & 17.0 \\
\hline \multicolumn{6}{|c|}{$\begin{array}{l}\begin{array}{l}\text { Texts written in the collaborative writing groups, where the students were not allowed to choose partners for } \\
\text { small groups }\end{array} \\
\end{array}$} \\
\hline 4 & 24 & 23 & 8 & 7 & 18 \\
\hline 5 & 22 & 21 & 6 & 6 & 15 \\
\hline 6 & 21 & 19 & 7 & 6 & 13 \\
\hline Average score & 22.3 & 21.0 & 7.0 & 6.3 & 15.3 \\
\hline \multicolumn{6}{|c|}{ Texts written under collaborative prewriting conditions } \\
\hline 7 & 28 & 29 & 10 & 9 & 20 \\
\hline 8 & 27 & 29 & 9 & 9 & 20 \\
\hline 9 & 26 & 26 & 9 & 9 & 18 \\
\hline 10 & 25 & 26 & 8 & 8 & 19 \\
\hline 11 & 25 & 24 & 8 & 6 & 17 \\
\hline 12 & 23 & 19 & 7 & 7 & 18 \\
\hline Average score & 25.7 & 25.5 & 8.5 & 8.0 & 18.7 \\
\hline \multicolumn{6}{|c|}{ Texts written with no collaboration } \\
\hline 13 & 27 & 26 & 9 & 9 & 19 \\
\hline 14 & 21 & 24 & 8 & 8 & 15 \\
\hline 15 & 18 & 25 & 7 & 6 & 14 \\
\hline 16 & 16 & 23 & 6 & 7 & 14 \\
\hline 17 & 16 & 25 & 5 & 8 & 13 \\
\hline 18 & 13 & 16 & 6 & 5 & 11 \\
\hline Average score & 18.5 & 23.2 & 6.8 & 7.2 & 14.3 \\
\hline
\end{tabular}

Our results vary depending on when collaboration occurs (before or during the writing) as far as the outcome of collaborative writing was concerned, the student-selected groups noticeably outperformed the teacher-assigned ones. Compared to the texts written in the collaborative writing groups, where the students were not allowed to choose partners for small groups, an average score was 25.7 and 22.3 for the originality of the plot, 25.3 and 21.0 for language and style, 8.3 and 7.0 for text admissibility, 8.0 and 6.3 for didactic function, 17.0 and 15.3 for characters. The results showed that participants in student-selected groups had a higher tendency to write longer texts and to add an appropriate conclusion that would properly wrap up the writing. The substantial difference between the scores of each of the student-selected groups has not been revealed.

The highest scores were given to the texts written under collaborative prewriting conditions: $25.7,25.5$, 8.5, 8.0 and 18.7 respectively. The lowest average score got the texts written with no collaboration: 18.5, 23.2, 6.8, 7.2 and 14.3. Noteworthy, among the last category of participants there were the most significant differences in the scores on all indicators. 
Table 2 reveals the perceptions and attitudes of students about collaborative writing. The first number in table 2 shows the number of students from 3 collaborative writing groups of 4 people, where the students were allowed to choose partners for small groups. The second number illustrates the number of students from 3 collaborative writing groups of 4 people, where the students were not allowed to choose partners.

Table 2. Collaborative writing tasks for future journalists from students' perspective (24 participants)

\begin{tabular}{|c|c|c|c|c|c|c|c|}
\hline No. & Item & $\begin{array}{l}\text { Strongly } \\
\text { Disagree }\end{array}$ & Disagree & Neutral & Agree & $\begin{array}{l}\text { Strongly } \\
\text { Agree }\end{array}$ & $\begin{array}{l}\text { No } \\
\text { responce }\end{array}$ \\
\hline 1 & $\begin{array}{l}\text { Do you like collaborative } \\
\text { writing tasks? }\end{array}$ & $0 / 2$ & $0 / 2$ & $1 / 0$ & $8 / 6$ & $3 / 2$ & 0 \\
\hline 2 & $\begin{array}{l}\text { Do you participate in } \\
\text { social networking groups } \\
\text { in your area of training? }\end{array}$ & $1 / 2$ & $9 / 9$ & 0 & $2 / 1$ & 0 & 0 \\
\hline 3 & $\begin{array}{l}\text { Could you express } \\
\text { creativity in group work? }\end{array}$ & $0 / 3$ & $1 / 6$ & 0 & $9 / 3$ & $2 / 0$ & 0 \\
\hline 4 & $\begin{array}{l}\text { Did you try to avoid } \\
\text { responsibility? }\end{array}$ & $3 / 0$ & $8 / 2$ & 0 & $0 / 3$ & $1 / 7$ & 0 \\
\hline 5 & $\begin{array}{l}\text { Was it fun to discuss } \\
\text { issues in a group? }\end{array}$ & $1 / 3$ & $2 / 4$ & 0 & $7 / 4$ & $2 / 1$ & 0 \\
\hline 6 & $\begin{array}{l}\text { Do you criticise the } \\
\text { opinions you disagree } \\
\text { with? }\end{array}$ & $1 / 1$ & $1 / 1$ & $1 / 0$ & $8 / 7$ & $1 / 3$ & 0 \\
\hline 7 & $\begin{array}{l}\text { Do you think } \\
\text { collaborative writing is } \\
\text { useful for your } \\
\text { professional } \\
\text { development? }\end{array}$ & $1 / 1$ & $0 / 2$ & 0 & $9 / 7$ & $2 / 2$ & 0 \\
\hline 8 & $\begin{array}{l}\text { Did you hide your ideas } \\
\text { that are successful in } \\
\text { your opinion, fearing to } \\
\text { share authorship with } \\
\text { others? }\end{array}$ & $9 / 4$ & $2 / 0$ & 0 & $1 / 5$ & $0 / 2$ & $0 / 1$ \\
\hline 9 & $\begin{array}{l}\text { Did your activity depend } \\
\text { on the activity of other } \\
\text { group members? }\end{array}$ & $1 / 1$ & $1 / 0$ & $1 / 2$ & $8 / 7$ & $1 / 2$ & 0 \\
\hline 10 & $\begin{array}{l}\text { Do you think that you } \\
\text { were unfairly evaluated } \\
\text { during group work? }\end{array}$ & $5 / 1$ & $4 / 1$ & 0 & $1 / 7$ & $2 / 3$ & 0 \\
\hline
\end{tabular}

Results of students' survey on collaborative writing tasks illustrated that most of the students, who participated in collaborative writing (24), like collaborative writing tasks (19), can show their creativity while working in groups (14), have fun when arguing with group members (14), use to criticise the opinions they disagree with (19), think collaborative writing is useful for their professional development (20) and suppose their activity depends on the activity of other group members (18). Unfortunately, most students do not participate in social networking groups that have to do with the direction of their training (21), try to avoid responsibility (13), think that they are unfairly evaluated during group work (13). Research confirms that most of the negative effects are more noticeable in the collaborative writing groups, where the students were not allowed to choose partners for small groups.

The second survey questionnaire captured the perceptions and attitudes of university teachers about collaborative writing (table 3 ).

Our results revealed university teachers' opinion on collaborative writing. In particular, most of the teachers think group work is effective (10 of 12 participants), students can show their creativity while working in groups (8), skills improved by collaborative writing help to accomplish individual tasks (11). Half of the teachers think students' performance can be assessed completely objectively. Moreover, 11 teachers stated they learned from students when they presented the results of a group work (11). 
Table 3. Collaborative writing tasks for future journalists from university teachers' perspective (12 participants)

\begin{tabular}{|c|c|c|c|c|c|c|c|}
\hline No & Item & $\begin{array}{l}\text { Strongly } \\
\text { Disagree }\end{array}$ & Disagree & Neutral & Agree & $\begin{array}{l}\text { Strongly } \\
\text { Agree }\end{array}$ & $\begin{array}{l}\text { No } \\
\text { responce }\end{array}$ \\
\hline 1 & $\begin{array}{l}\text { Do you think group } \\
\text { work is effective? }\end{array}$ & 1 & 1 & 0 & 9 & 1 & 0 \\
\hline 2 & $\begin{array}{l}\text { Can the students show } \\
\text { their creativity while } \\
\text { working in groups? }\end{array}$ & 1 & 3 & 0 & 8 & 0 & 0 \\
\hline 3 & $\begin{array}{l}\text { Do you criticise the } \\
\text { opinions you disagree } \\
\text { with? }\end{array}$ & 0 & 3 & 0 & 9 & 0 & 0 \\
\hline 4 & $\begin{array}{l}\text { Do you learn from } \\
\text { your students when } \\
\text { they present the } \\
\text { results of a group } \\
\text { work? }\end{array}$ & 0 & 1 & 0 & 11 & 0 & 0 \\
\hline 5 & $\begin{array}{l}\text { Do you think that } \\
\text { skills improved by } \\
\text { collaborative writing } \\
\text { help to accomplish } \\
\text { individual tasks? }\end{array}$ & 0 & 1 & 0 & 11 & 0 & 0 \\
\hline 6 & $\begin{array}{l}\text { Do you think that } \\
\text { performance of each } \\
\text { group member can be } \\
\text { assessed completely } \\
\text { objectively? }\end{array}$ & 3 & 3 & 0 & 6 & 0 & 0 \\
\hline
\end{tabular}

Interviewing university teachers at the meeting of the Department of Publishing and Editing, we revealed, that collaborative writing tasks give students the opportunity to talk about what they are supposed to do; assign task roles, discuss the topic and develop original ideas, to develop negotiating skills, to find and discuss different solutions, improve problem-solving and helping skills.

It was mentioned by all teachers that collaborative writing is ineffective if students take a passive role. Teachers consider writing projects (books for kids, journals, scientific articles) to be the main type of collaborative writing. Such tasks involve interaction throughout all phases of the writing process in which students construct a single, co-authored text.

Some teachers (5 of 12) encounter challenges while organising collaborative writing activities, such as designing appropriate group tasks, composing groups, problems with time control. Other challenges are coordinating group activities, lack of communicative and collaborative skills in students, free-riding, when collaborating on group assignments, problems with evaluation (when low-contributing members still get the same grade as active members). Some students contributed most, while others worked less when completing their own particular tasks. Individual students do not want to expose their lack of understanding to others and feel embarrassed. Sometimes there are difficulties in coming to an agreement when influential members, whose ideas were mostly accepted by the majority of their fellow group members, do not accept critic, tending to underestimate the intellectual capacity of other group members.

Classroom management challenges teachers. Students working together need to talk to each other and this may lead to off-topic chatters and class confusion. Teachers revealed a considerable amount of off-task behaviour among the members of collaborative groups.

The analysis of interviews with teachers allowed identifying several types of students' writing behaviour:

Motivated writers engage in collaborative writing because they experience interest and enjoyment while doing tasks, and this behaviour does not require rewards or the avoidance of punishments.

A dependent writer has a lack of knowledge about the content and organisation of a particular task, needs a succinct action plan for action and needs a leader.

Self-confident writers think they know how to work and try to lead a group but may have difficulties with unusual tasks or in unusual conditions. It is difficult for them to recognise their own mistakes.

A resistant writer both lacks knowledge about the content and organisation of a particular task and has no motivation for learning. At the same time, he or she is not inclined to accept help, including planning sessions for writing draft components, oral and written feedback on drafts. 
A sporadic writer repeatedly fails to meet deadlines for particular pieces of the task. However, unexpectedly such a learner can produce quality results from time to time.

Such individual differences in writing behaviour affect the assessment of each particular member of the group. Analysing learners' roles and attitudes in collaborative writing should be conducted during the prewriting discussions. It can help to understand the nature of the interaction between the students throughout the prewriting discussion and reveal the students who actively participate in creating, evaluating, and giving feedback to peers' ideas, or the students who passively gain the ideas.

\section{Discussion and Conclusions}

In general, this investigation supports the positive findings of the previous studies. This study deepens earlier research on students' attitudes towards collaborative writing by exploring the results of texts writing under different conditions. The study sheds new light on the importance of prewriting group discussion. It also investigates teachers' attitudes towards collaborative writing. Group tasks and activities that integrate teamwork broaden the diversity of skills students can develop within their curriculum, giving students interpersonal and negotiating skills. Collaborative writing is beneficial for improving writing, providing the opportunity to pool ideas and having positive emotional and social effects (Zheng et al., 2018).

In contrary to previous results (Mozaffari, 2017), our findings prove that participants in student-selected groups produce significantly better texts in terms of originality, grammar and vocabulary, text admissibility, didactic function and characters. So, the students' voice should be taken into account when the teacher forms small groups. It also requires educators to be aware of their learners' individual characteristics as these may determine if and how learners benefit (Schnaubert and Bodemer, 2019).

Unexpected results were that the highest score got texts written individually after prewriting group discussion. These results mean it is necessary to implement individual writing activities with prewriting discussions, making the students become more independent.

The success of collaborative writing depends on students' feedback and engagement. Working together and interacting throughout the writing process, the students contribute to the planning, generation of ideas, revision of the group project. Students develop critical thinking skills while analysing texts, arguments and composing their papers. The students get an opportunity to see the bigger picture, which helps "the conceptually not-ready student" (Janssen et al., 2009).

Limitations of the study may be related to the educational field: what is appropriate for journalistic education may not be acceptable in other educational fields. Several notes are pointed out as drawbacks to collaborative writing. In the first place, a great challenge of collaborative writing is that it is dependent on a successful group dynamic. Conflicts between the group members may reduce their ability to work together. Secondly, the proactive students may complain of free-riding of the inactive group members. The students may ignore inactive members participation. Additionally, it is often difficult to assess an individual member of a group; hence, all the group mates are awarded the same grade regardless of the degree of participation. The results confirm the study of Diezmann (2005), that it can be difficult for teachers to determine whether each student participated equally in the process of creating the text.

Despite the limitations of this study, its findings have yielded several insights for classroom practice. Before creating student groups, it is recommended for teachers to measure their attitudes towards collaborative writing and try to avoid grouping together students who share negative attitudes. Teachers need to observe students' changes in attitudes during the activity.

We disagree with Lamminpää and Vesterinen (2018), who states that collaborative writing does not seem to consistently result in a better product, and does not necessarily result in visibly improved writing skills. When group members have gaps in their knowledge base that can be filled by other group members, the collaborative is superior to individual learning. Our results contradict Retnowati, Ayres, and Sweller (2018), who supposed: when group members have no prerequisite knowledge gaps, then collaborative learning is redundant and as a consequence inferior to individual learning.

Pre-existing friendship is the major criterion upon which students rely in selecting partners. In line with prior research (Basta, 2011) we indicated that whenever students have a free choice of group members, they prefer to work with their friends with whom they feel more relaxed.

We should highlight students' activities in exchanging, evaluating, and organising ideas. This type of learning activity requires students to articulate their own points of view, to bear responsibility and listen to the views of others. However, at the same time in this article, we proved that there is a need for implementing prewriting group discussions, in which students have opportunities to interact during the prewriting phase but then compose texts individually. This method gives a teacher an ability to deal with the problems of "lazy" or "slack" group members and the resultant unfair workload distribution. 
The findings of the study have shown that the majority of students and teachers confirmed positive attitudes about cooperative learning activities. Collaborative writing contributes to students' learning outcomes and prepares them for teamwork. But we got the evidences of unequal participation of students, especially in small groups where the partners were not familiar with each other.

Students need to become aware of their strengths and weaknesses in group work and take responsibility for their contribution to the common result. The teacher's role is primarily to provide feedback on time, help to resolve conflicts and help students manage the time. To evaluate individual results correctly it is necessary to understand the role of each student in collaborative writing.

Our results highlighted the issues and benefits in student-centred collaborative writing in journalistic education, comparing the texts written under different conditions. It is important for journalistic education because it is intended to facilitate the diversity of the educational process.

The key points of the research are the following.

1. There is a difference in the quality of texts written by students under different conditions. The highest score got texts written after prewriting group discussion. The texts prepared by the students who were allowed to choose partners for small groups gained a higher score than written by students who were not familiar with each other. The participants who were allowed to choose partners for group work showed a greater degree of participation and more supportive behaviour. The lowest score got texts written without any collaboration.

2. The students' attitudes towards collaborative writing are: collaborative writing tasks help students to show their creativity while working in groups, they have fun when discussing issues with group members, they tend to criticise the opinions they disagree with, they think collaborative writing is useful for professional development, their activity depends on the activity of other group members. The university teachers' positive attitudes towards collaborative writing are: students can show their creativity while working in groups, advantages of collaborative writing help to accomplish individual tasks, developing negotiating skills, improving problem-solving and helping skills. The negative attitudes are the following: problems with time control, danger of free-riding, problems with composing groups and evaluation.

This study illustrates that the students' attitudes towards collaborative writing can be influenced by many factors, including beliefs about collaborative tasks and experiences, peer assistance, and group friendship. Such information helps teachers to gain a better understanding of how students' attitudes toward collaborative writing may affect their readiness to benefit from such activities. The article also demonstrates the use of a peer assessment that enables senior students to show themselves in a professional role.

Methodologies of collaborative writing in other areas of education should be explored in the future. It should be clarified how the productivity of collaborative writing depends on available time frames and the size of the group. Since collaborative writing has been reported as a strategy for producing high-quality writing, it would be valuable to gather more information on how attitudinal changes towards the process affected the quality of the final projects.

\section{References}

Ayodele, V., Akinkurolere, S., Ariyo, K., Mahmud, O., \& Abuya, E. (2017). The teaching of essays, articles and letter writing: cooperative teaching approach. Asian Research Journal of Arts \& Social Sciences, 4(2), 1-7. https://doi.org/10.9734/ARJASS/2017/35161

Baker, T., \& Clark, J. (2010). Cooperative learning - a double-edged sword: a cooperative learning model for use with diverse student groups. Intercultural Education, 21(3), 257-268. https://doi:10.1080/14675981003760440

Baker, D., Day, R., \& Salas. E. (2006). Teamwork as an Essential Component of High-Reliability Organizations. Health Research and Educational Trust, 41, 1576-1598. https://doi:10.1111/j.1475-6773.2006.00566.x

Basta, J. (2011). The role of the communicative approach and cooperative learning in higher education. Linguistics and Literature, 9 , 125-143. Retrieved 10 September 2019 from http://facta.junis.ni.ac.rs/lal/lal201102/lal201102-06.pdf

Bruffee, K. (2007). A short course in writing: Composition, collaborative learning, and constructive reading (Fourth edition.). New York: Pearson Longman.

Chen, W., \& Yu, S. (2019). A longitudinal case study of changes in students' attitudes, participation, and learning in collaborative writing. System, 82, 83-96. https://doi.org/10.1016/j.system.2019.03.005

Creswell, J. W. (2014). Research design: Qualitative, quantitative and mixed methods approaches. SAGE

Diezmann, C. (2005). Supervision and scholarly writing: writing to learn to write. Reflective Practice, 6(4), $443-457$. https://doi:10.1080/14623940500300491

Dowell, N., Nixon, T., \& Graesser, A. (2018). Group communication analysis: A computational linguistics approach for detecting sociocognitive roles in multiparty interactions. Behavior Research Methods, 51, 1007-1041. https://doi.org/10.3758/s13428-018-1102-z

Fernandez Dobao, A. (2012). Collaborative writing tasks in the L2 classroom: Comparing group, pair, and individual work. Journal of Second Language Writing, 21, 40-58. https://doi.org/10.1016/j.jslw.2011.12.002

Janssen, J., Erkens, G., Kirschner, P., \& Kanselaar, G. (2009). Influence of group member familiarity on online collaborative learning. Computers in Human Behaviour, 25, 161-170. https://doi.org/10.1016/j.chb.2008.08.010 
Hashem, A. (2018). The Effectiveness of Using Online Blogging for Students' Individual and Group Writing. International Education Studies, 11(1), 44-51. https://eric.ed.gov/?id=EJ1165114

Hei, M., Strijbos, J., Sjoer, E., \& Admiraal, W. (2014). Collaborative learning in higher education: lecturers' practices and beliefs. Research Papers in Education, 30(2), 232-247. https://doi:10.1080/02671522.2014.908407

Inoshita, A., Garland, K., \& Sims, K. (2019). English Composition: connect, collaborate, communicate. USA: University of Hawai i.

Gardner, M. (2017). Writing together for academic publication as a youth-adult PAR team: moving from distance and distaste towards transformative engagement. Educational Action Research, 26 (2), 205-219. https://doi.org/10.1080/09650792.2017.1329093

Kellogg, R. (1990). Effectiveness of prewriting strategies as a function of task demands. The American Journal of Psychology, 103, 327-342. https://doi.org/10.2307/1423213

Kozlov, M., \& Große, C. (2016). Online collaborative learning in dyads: effects of knowledge distribution and awareness. Computers in Human Behavior, 59, 389-401. https://doi.org/10.1016/j.chb.2016.01.043

Lamminpää, J., \& Vesterinen, V. (2018). The use of humour during a collaborative inquiry. International Journal of Science Education, 40 (14), 1718-1735. https://doi.org/10.1080/09500693.2018.1508926

Le, H., Janssen, J., \& Wubbels, T. (2017). Collaborative learning practices: teacher and student perceived obstacles to effective student collaboration. Cambridge Journal of Education, 48(1), 103-122. https://doi:10.1080/0305764x.2016.1259389

Li, M., \& Kim, D. (2016). One wiki, two groups: Dynamic interactions across ESL collaborative writing tasks. Journal of Second Language Writing, 31, 25-42. https://doi.org/10.1016/j.jslw.2016.01.002

Li, M. (2018). Computer-mediated collaborative writing in L2 contexts: an analysis of empirical research. Computer Assisted Language Learning, 31(8). 882-904. https://doi.org/10.1080/09588221.2018.1465981

McDonough, K., \& García Fuentes, C. (2015). Writing to learn language: The effect of writing task on Colombian EFL learners' language use. TESL Canada Journal, 32(2), 67-79. https://doi.org/10.18806/tesl.v32i2.1208

Mozaffari, S. (2017). Comparing student-selected and teacher-assigned pairs on collaborative writing. Language Teaching Research, 21(4), 496-516. https://doi.org/10.1177/1362168816641703

Prinsley, R., \& Baranyai, K. (2015). STEM Skills in the Workforce: What Do Employers Want? Canberra: Australian Government Chief Scientist.

Retnowati, E., Ayres, P., \& Sweller, J. (2018). Collaborative learning effects when students have complete or incomplete knowledge. Applied Cognitive Psychology, 32 (6), 681-692. https://doi.org/10.1002/acp.3444

Riebe, L., Girardi, A., \& Whitsed, C. (2016). A Systematic literature review of teamwork pedagogy in higher education. Small Group Research, 47 (6), 619-664. https://doi:10.1177/1046496416665221

Roseth, C., Johnson, D. \& Johnson. R. (2008). Promoting early adolescents' achievement and peer relationships: the effects of cooperative, competitive, and individualistic goal structures. Psychological Bulletin, 134, 223-246. https://doi.org/10.1037/0033-2909.134.2.223

Schnaubert, L., \& Bodemer, D. (2019). Providing different types of group awareness information to guide collaborative learning. International Journal of Computer-Supported Collaborative Learning, 4(1), 7-51 . https://doi.org/10.1007/s11412-018-9293-y

Storch, N. (2011). Collaborative writing in L2 contexts: processes, outcomes and future directions'. Annual Review of Applied Linguistics, 31, 275-288. https://doi.org/10.1017/S0267190511000079

Storch, N. (2013). Collaborative writing in L2 classrooms. Bristol, UK: Multilingual Matters.

Storch, N. (2005). Collaborative writing: Product, process, and students' reflections. Journal of Second Language Writing, 14, 153173. https://doi.org/10.1016/j.jslw.2005.05.002

Wahyudi, D., Hilaluddi, H., \& Ader, L. (2018). The Impact of Collaborative Learning on Students' Writing Ability and Their Motivation in Writing at MTs Negeri 1 Konawe. Journal of Language Education and Educational Technology, 3 (1). http://dx.doi.org/10.33772/jleet.v3i1.6705

Wigglesworth, G., \& Storch, N. (2009). Pair versus individual writing: Effects on fluency, complexity and accuracy. Language Testing, 26, 445-466. https://doi.org/10.1177/0265532209104670

Wilson, L., Ho, S., \& Brookes, R. (2017). Student perceptions of teamwork within assessment tasks in undergraduate science degrees. Assessment \& Evaluation in Higher Education, 43(5), 786-799. https://doi:10.1080/02602938.2017.1409334

Zheng, Y., Li, C., Liu, S., \& Lu, W. (2018). An improved genetic approach for composing optimal collaborative learning groups. Knowledge-Based Systems, 139, 214-225. https://doi:10.1016/j.knosys.2017.10.022 